\title{
The lost fortress of Onoguris? Newly discovered sixth-century AD fortifications at Khuntsistsikhe, western Georgia
}

\author{
Paul Everill ${ }^{1}$, Besik Lortkipanidze ${ }^{2}$, Nikoloz Murghulia ${ }^{3}$, Ian Colvin ${ }^{4}$ \\ \& Davit Lomitashvili ${ }^{5}$
}

\section{Introduction}

The village of Khuntsi is located in the Martvili municipality of Samegrelo, western Georgia, on the west bank of the Tskhenistskali River, on the road that links Martvili, Khoni and Kutaisi. A few short sections of wall on Kukiti Hill (known locally as 'Najikhu', translating roughly from Mingrelian as 'ruins (remains) of a castle') indicate the presence of a fortress. Six years ago, the installation of a mobile phone mast and associated infrastructure without consultation with the appropriate archaeological agencies revealed and damaged archaeological structures. Animal bone and fragments of pottery were retrieved, and are currently stored in the school in Khuntsi. It was information from a local school teacher, Zoya Gadelia, that led the Anglo-Georgian Expedition to Nokalakevi to investigate the site in 2015.

\section{Historical background: the search for Onoguris}

Agathias of Myrina or Scholasticus, a sixth-century Byzantine historian, is among those who described military engagements in west Georgia in AD 542 between Byzantium and its Laz allies on the one side, and the Sassanid Persian Empire on the other. It was part of a confrontation that lasted for more than 20 years, and contemporaneous accounts describe it as the 'Great War of Egrisi'. Agathias (Historiarum Libri Quinque; Keydell 1967: II.22.3-III.3.8-III.7; IV.9.6; IV.11) refers several times to the fortress of Onoguris, which was strategically important to both the Byzantines and the Iranians, and he notes this as

1 Department of Archaeology, University of Winchester, Sparkford Road, Winchester SO22 4NR, UK (Email: paul.everill@winchester.ac.uk)

2 Parmen Zakaraia Nokalakevi Architectural-Archaeological Museum-Reserve, Nokalakevi, Samegrelo, Georgia (Email:beso_lort@yahoo.com)

3 Department of Medieval Archaeology, S. Janashia Museum of Georgia, Georgian National Museum, Rustaveli Avenue 3, 0105 Tbilisi, Georgia (Email:nikomurgulia@yahoo.com)

4 Cambridge SCP, University of Cambridge, 11 West Road, Cambridge CB3 9DP, UK (Email: idc30@cam.ac.uk)

5 National Agency for Cultural Heritage Preservation of Georgia, Krtsanisi Street 58, 0105 Tbilisi, Georgia (Email: dlomitashvili@gmail.com) 


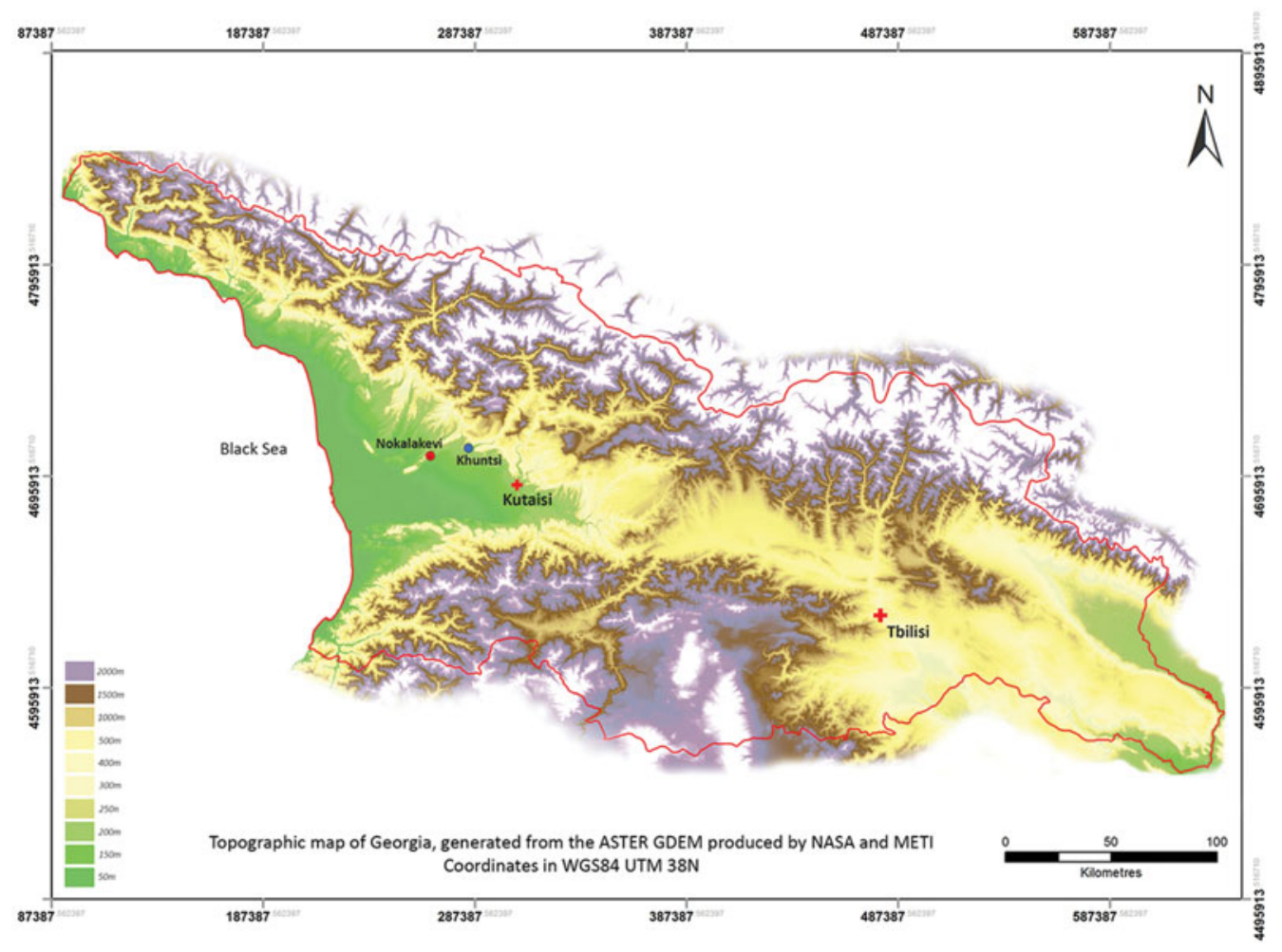

Figure 1. Physical map of Georgia, showing the location of Nokalakevi and Khuntsi on the southern edge of the Greater Caucasus overlooking the Colchian Plain.

the ancient name of the place, known as Hagios Stephanos in his day (Stepantsminda in Georgian, Saint Stephen in English). While translating Agathias's work, Kaukhchishvili (1936: 59-62, Note 1) tried to identify the location of this fortress. He linked its name with the Unagira Mountain that is situated on the border of the Martvili and Khoni districts. $\mathrm{He}$ also noted Agathias's account of how, in AD 554, Persian forces occupied the Kingdom of Lazika up to the River Tskhenistskali, known as the Hippis in classical sources, with Byzantine forces maintaining fortified positions to the west of the river (Kaukhchishvili 1936: 38-41, Note 2). Based on this account, Kaukhchishvili felt that the fortress should be on the eastern border of Lazika, approximately halfway between Tsikhegoji-Archaeopolis (the capital of Lazika) in the west and Kutaisi in the east (Figure 1).

Kaukhchishvili also identified Onoguris with the fortress of Ukimerion (usually referred to as Uthimereos in western translations), and several suggestions have subsequently been made for the location of Onoguris. Berdzenishvili (1975: 463-65) also connected its name with the Unagira Mountain, and searched for it in the vicinity of Bandza and Nokalakevi. He described a temptation to link the village of Onoghia situated near Bandza with Onoguris; Onoghia is, however, located on the plain with no suitable location for a fortress of such importance. In the 1980s, the Nokalakevi expedition undertook archaeological excavations at Abedati fortress, in the Martvili district, and publications (Zakaraia \& (C) Antiquity Publications Ltd, 2017 
Kapanadze 1991; Lekvinadze 1993) linked the site with Onoguris. Braund (1994: 306), noting the existence of a sixth- or seventh-century inscription calling on Saint Stephen in the village of Sepieti's basilica, suggested Sepieti as the site of Onoguris (Braund \& Sinclair 2000: 3-4, 9). In recent years, this issue was discussed by Pailodze (2003), who, in studying the work of Agathias and the geographic descriptions, stated that it was impossible to identify Abedati with Onoguris because of the distance from Kutaisi. He also noted that the mountain ridge of Unagira begins at the border with Imereti, near the village of Matkhoji on the opposite bank of the River Tskhenistsqali from the hill of upper Khuntsi, known as 'Najikhu'. Pailodze (2003) reported some standing remains on the hill at Khuntsi, which he suggested might be the remains of Onoguris, but he did not excavate. At the same time, the previous association of Abedati with Onoguris was challenged by Lomitashvili (2003: 210), who noted that most of the material culture excavated considerably post-dated the 'Great War of Egrisi'.

During the 2014 Nokalakevi field season, the authors visited the hill of upper Khuntsi and observed for themselves the remains of various structures. In addition to the etymological discussion described above, it was also noted that the nearby River Nogela might be connected with Onoguris. The date and function of the structural remains, however, were unclear and plans were made for an initial archaeological evaluation of the site in 2015.

\section{Archaeological investigation}

An archaeological evaluation, through the excavation of four test pits, was undertaken by a small team from the Anglo-Georgian Expedition to Nokalakevi in 2015, referring to the site as Khuntsistsikhe ('the fortress of Khuntsi'). The initial aim was to examine archaeological layers inside the possible fortress, to study the stratigraphy and to retrieve finds in order to determine a site chronology. During a survey of the site, it was observed that large areas of bracken appeared to be growing over areas with a higher density of stone rubble, and, in places, short sections of surviving wall face could be observed along the edge of the bracken. These observations were used to produce conjectural wall lines, and these appear to have been confirmed by evidence from Test Pit 3, which revealed a substantial section of wall. A GPS survey of the site has demonstrated that the fortress occupied at least $70 \times 80 \mathrm{~m}$, larger than many known west-Georgian fortified sites of this period, and is double the size of Abedati. Ceramic material from a context in Test Pit 3 was sent to the Research Laboratory for Archaeology and the History of Art at the University of Oxford for analysis, and was dated through optically-stimulated luminescence to AD $646(+/-160)$. The same context produced an elaborate stamped decoration on the underside of an amphora handle, and, although after some investigation, no other examples of this motif could be found beyond western Georgia, a single example of a similar decoration was found in the Nokalakevi archive at the S. Janashia Museum of Georgia (Figure 2). This example had been found outside the walls of Nokalakevi itself in 1981, from a layer that had been dated by the imported wares within it to the fifth/sixth centuries AD.

Investigation of the site was significantly expanded in 2016, with five trenches designed to shed further light on the structural remains indicated by the test pits (Figure 3). This 

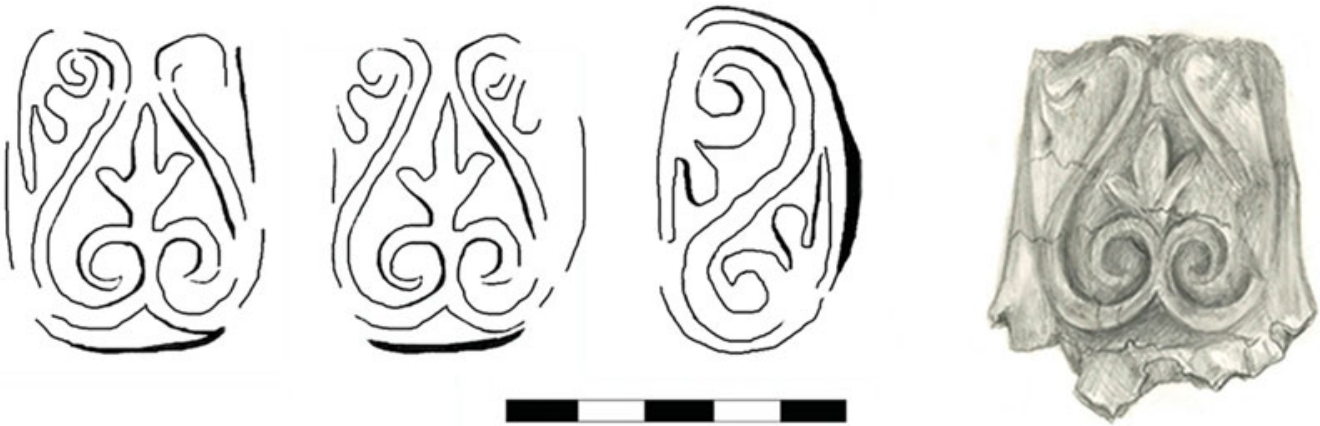

The identical 'floral' stamped handle decoration found by the Anglo-Georgian Expedition during work at Khuntsi in 2015 (left), and 2016 (second left), alongside a stylistically similar motif found at Nokalakevi in 1981. Far right, illustration of the 2016 handle fragment by S. Laitadze

Figure 2. The stamped amphora handles found at Khuntsi and Nokalakevi.

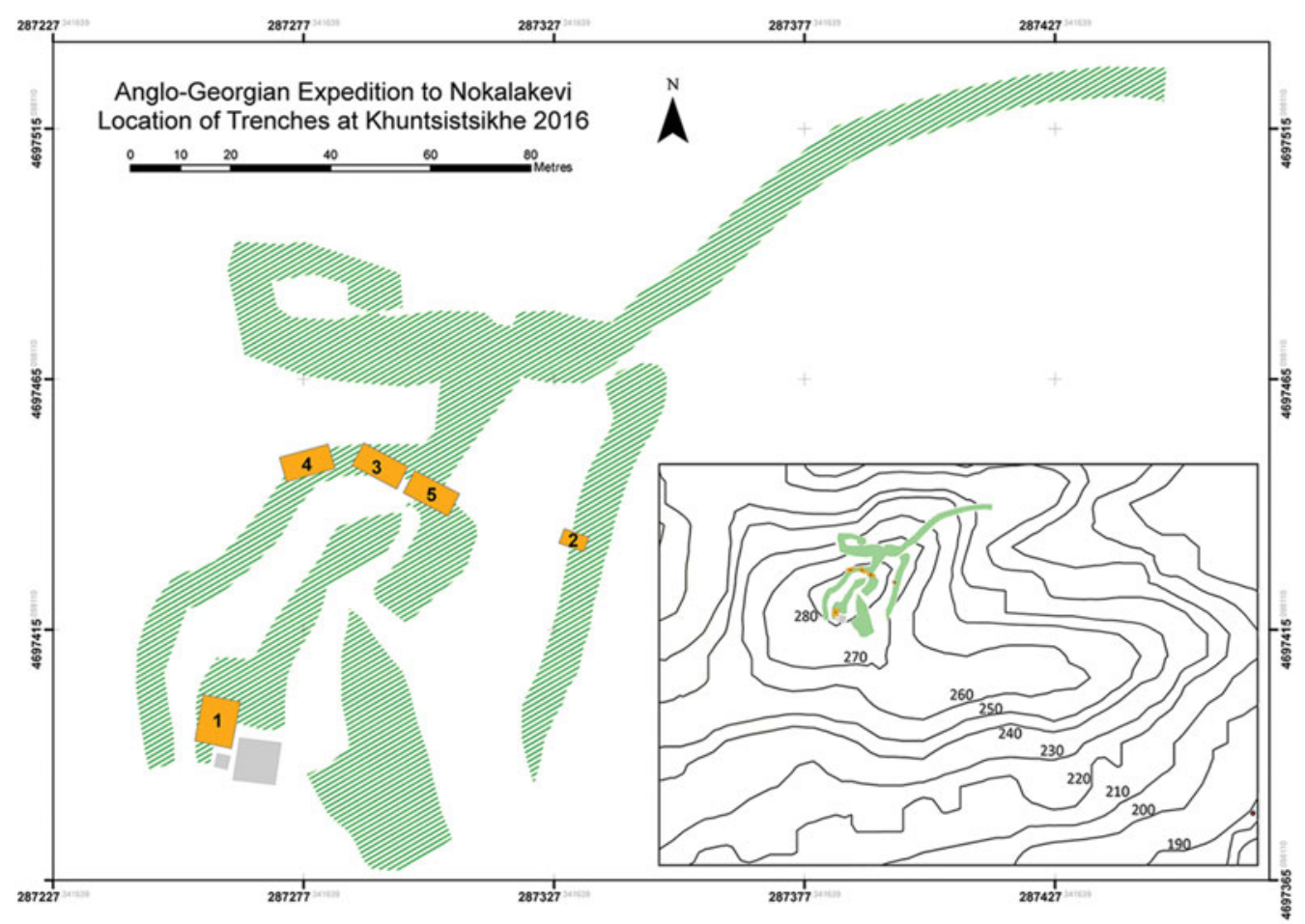

Figure 3. The location of trenches at Khuntsi in 2016. Green shaded areas indicate dense bracken growth overlying standing andlor collapsed walls.

archaeological work revealed more information on the size and scale of the fortifications, exposing a $25 \mathrm{~m}$-length of wall along the northern edge of the crown of the hill (Figure 4). Excavations also produced an additional example of the stamped handle decoration and a large number of fragmentary fifth- to sixth-century ceramics, including amphorae, dergi (cooking vessels), pithoi (large storage vessels) and ceramic building material. A trench at the (C) Antiquity Publications Ltd, 2017 


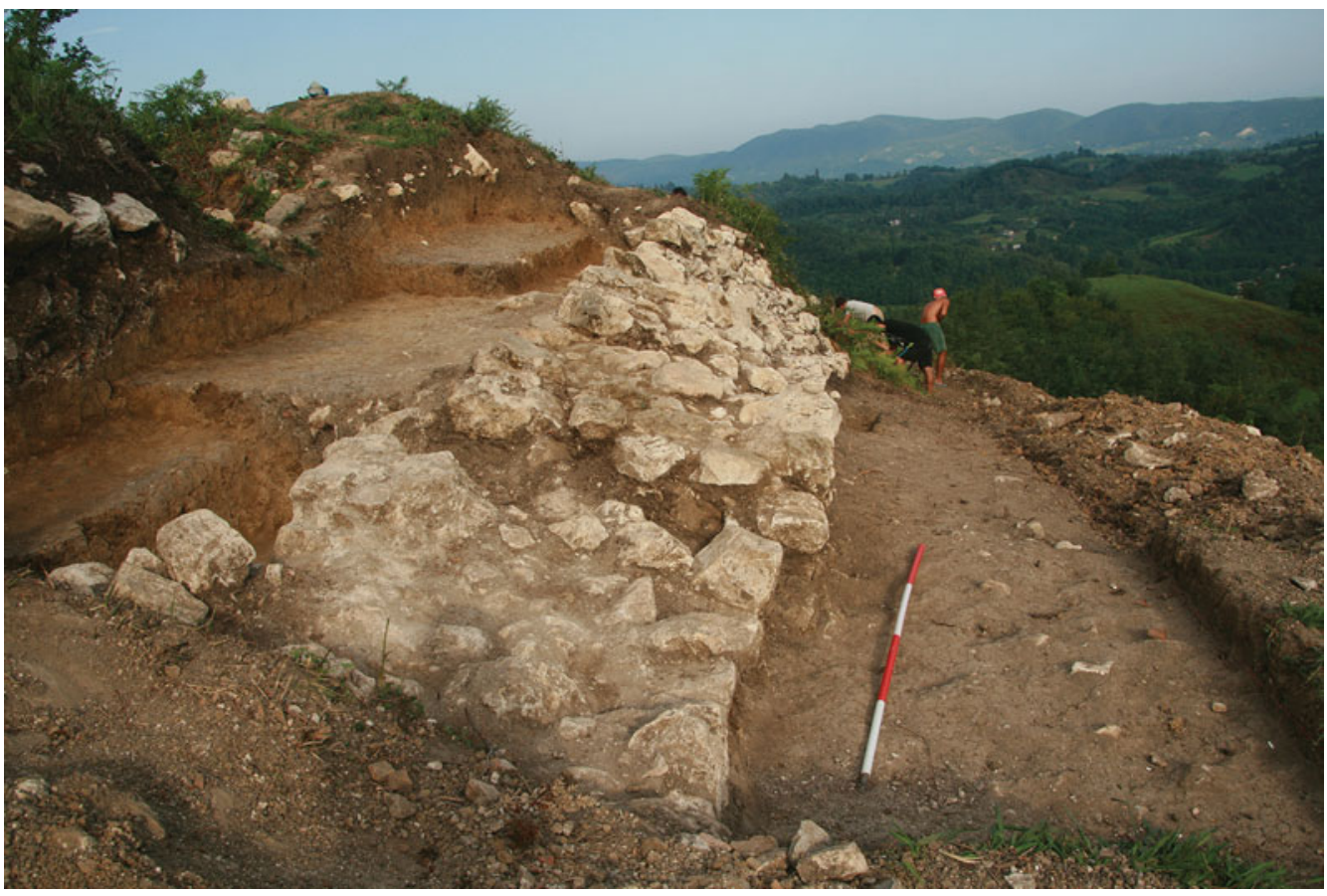

Figure 4. A section of the fortification wall along the northern edge of the top of the hill.

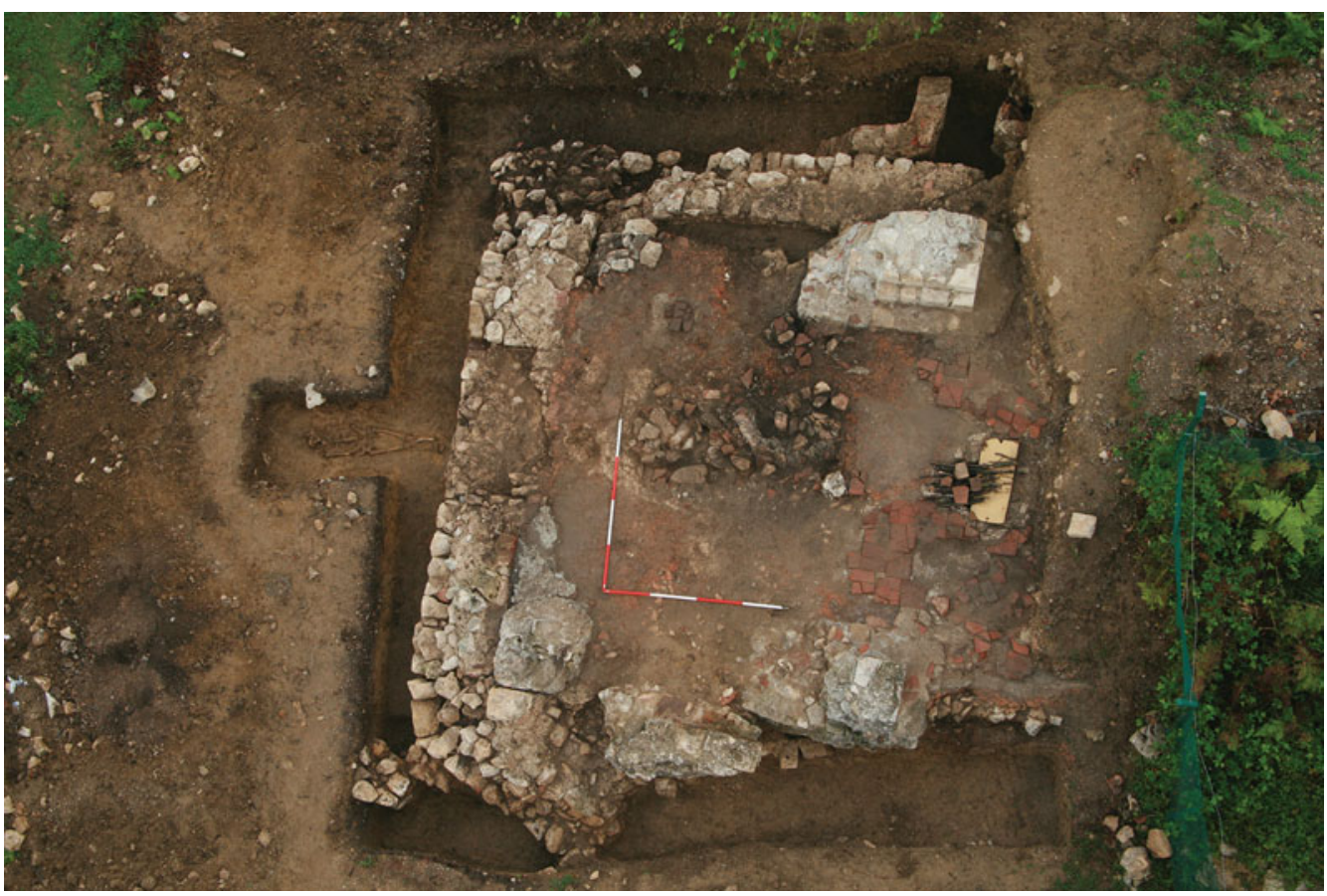

Figure 5. Overhead photograph (north at the top) showing the building exposed at the top of the hill and a burial to the west. 
top of the hill revealed a hydraulic mortar floor with a finely ground ceramic pozzolanan additive that produced a more durable, waterproof surface-contained within further substantial stone walls (Figure 5). To the west of this building, an adult male skeleton was revealed. He had been buried in a supine position, with the head to the west and the arms crossed across his abdomen. Within the adjacent building, areas of tiled surface survived, as did four fragments of rectangular column bases. When a small hole unexpectedly appeared in the floor of this building, it was possible to observe elements of a vaulted space underneath. It is certainly conceivable that, rather than representing a tower within the fortress as was first thought, this building was a chapel with a vaulted crypt.

Further excavations in 2017 will seek to understand this building better, and additional work will take place to determine the precise layout of the external fortifications. It is clear that the remains at Khuntsi represent an early Byzantine-period fortified site. Although it cannot yet be stated that these are the remains of the Onoguris of Agathias's contemporaneous accounts, the evidence is certainly beginning to look compelling.

\section{References}

BeRDZENISHVILI, N. 1975. Issues of history of Georgia, VIII. Tbilisi: Metsniereba.

Braund, D. 1994. Georgia in antiquity: a history of Colchis and Transcaucasian Iberia, 550 BC-AD 562. Oxford: Clarendon.

Braund, D.C. \& T. Sinclair. 2000. Map 87 Pontus-Phasis, in R.J.A. Talbert (ed.) Barrington atlas of the Greek and Roman world. Princeton (NJ): Princeton University Press.

Kaukhchishvili, S. 1936. Georgica, III. Tfilisi: Tfilisi State University.

Keydell, R. 1967. Agathias: Historiarum Libri Quinque. Berlin: de Gruyter.

Lekvinadze, V. 1993. Abedati Fortress, in P. Zakaria (ed.) Nokalakevi-Archaeopolis, III: 209-22. Tbilisi: Metsniereba.

Lomitashvili, D. 2003. Central Colchis in $8^{\text {th }}$ c. BC-6 $6^{\text {th }}$ c. $A D$

(Tsikhegoji-Archaeopolis-Nokalakevi). Unpublished PhD dissertation, Georgian Academy of Science and Georgian State Museum.

Pailodze, A. 2003. Chronicle of Khoni, part II. Batumi: Alioni.

Zakaraia, P. \& T. Kapanadze. 1991. Fortifications and secular buildings of Tsikhegoji. Tbilisi: Metsniereba. 